\title{
Control TrialによるBCG投与成績
}

\author{
大阪回生、耳科
}

酒井俊一 - 山本邦之・吉田淳一

村田雅美・鈴木 湛

頭頸部悪性腫搷患者の根治的手術あるい放射 線治療終了後K B C A 投与行々, 再発䂆方, S uppressive 効果の有無を検討した。

投与群 47 例, 対照群 43 例であり, 症例割付 は同時期のものを無作為に行い, 表 1 のらに原 発部位, 病理組織診断, 直前治療法とも有意差な くバランスが取られている。

成績を局所制御率と粗生存率から比較検討した が，両群間は潘漂同様の経過を示し，B C G投与 の陽性効果は認めることがでをなかった。

なお B C G投与は肩部に皮内注射ないし管針法 によって行い，1回のものるあり繰返し投与した ものるある。その副作用として，皮内注射をした すの澧煌形成，発熱がみられたすのがあったが 重篤なるはは認好かった。

表 1. B C G 投与群 と対照群との症例構成

\begin{tabular}{|c|c|c|}
\hline & $\mathrm{BCG}$ 投与群 & 対照群 \\
\hline 全 症 例 数 & 47 & 43 \\
\hline 鼻・副 鼻 腔 & 31 & 33 \\
\hline 原 口 & 7 & 5 \\
\hline 発 軼 液 & 1 & 1 \\
\hline 部 咽 & 8 & 2 \\
\hline 位 頸 部リンパ節 & 0 & 2 \\
\hline 末 分 化 嵒 & 1 & 4 \\
\hline 病篇平上皮湶 & 37 & 31 \\
\hline 理＼cjkstart腺 & 0 & 3 \\
\hline 組 粘表皮 獥 & 1 & 1 \\
\hline 織 悪性 黒色腫 & 2 & 1 \\
\hline 診 肉 & 4 & 2 \\
\hline 断 悪性リンパ腫 & 2 & 1 \\
\hline 療 根 治 手 術 & 13 & 12 \\
\hline $\begin{array}{l}\text { 前法 放 射 線 治 療 } \\
\text { 治 }\end{array}$ & 34 & 31 \\
\hline
\end{tabular}

表 2 両群の治療成績比較

\begin{tabular}{|c|c|c|c|c|c|c|}
\hline \multirow[b]{2}{*}{ 局 } & \multirow[b]{2}{*}{ 半 } & \multirow[b]{2}{*}{ 年 } & \multicolumn{2}{|c|}{ B C G 投与群 } & \multirow{2}{*}{$\frac{\text { 対 照 }}{27 / 42}$} & \multirow{2}{*}{$\frac{\text { 群 }}{64 \%}$} \\
\hline & & & $32 / 47$ & $68 \%$ & & \\
\hline $\begin{array}{l}\text { 所 } \\
\text { 制 }\end{array}$ & & 年 & $23 / 47$ & $48 \%$ & $22 / 41$ & $53 \%$ \\
\hline 御 & 2 & 年 & $15 / 34$ & $44 \%$ & $16 / 39$ & $41 \%$ \\
\hline 率 & 3 & 年 & $13 / 32$ & $40 \%$ & $13 / 32$ & $40 \%$ \\
\hline 粗 & & 年 & $40 / 47$ & $85 \%$ & $37 / 43$ & $86 \%$ \\
\hline 生 & 2 & 年 & $21 / 34$ & $62 \%$ & $25 / 41$ & $61 \%$ \\
\hline $\begin{array}{l}\text { 存 } \\
\text { 率 }\end{array}$ & 3 & 年 & $16 / 28$ & $57 \%$ & $20 / 34$ & $59 \%$ \\
\hline
\end{tabular}

質問高橋头臣 (北里大耳)

おそらく BCGのSystemic な投与では それ程の効果はないのではないかと思う。局所 に使用するととが望ましいと思う。

答 酒井 腄盷内投与では，2例飞縮少効果があった。 